\title{
Enhancing healthcare quality by promoting work-life balance among nursing staff
}

\author{
Mrinal M. Varma, Angela S. Kelling, Shanta Goswami \\ University of Houston-Clear Lake, Houston, United States
}

Received: August 29, 2016

Accepted: September 14, 2016 Online Published: September 23, 2016

DOI: $10.5430 /$ jha.v5n6p58

URL: http://dx.doi.org/10.5430/jha.v5n6p58

\begin{abstract}
Nurses are fundamental to the functioning of any healthcare organization. However, nursing is a demanding and stressful profession. Excessive occupational stress can cause work-life conflict, decrease quality of care, and increase nurse resignation. It is essential that healthcare providers examine their organizational culture to ensure a supportive climate to maximize the well-being and work-life balance of nurses. With the improvement of the organizational culture, nurses will be able to provide top quality medical care, be more productive, and enhance patient satisfaction.
\end{abstract}

Key Words: Nursing, Work-life balance, Stress, Organizational culture

\section{INTRODUCTION}

In modern healthcare, nurses can be viewed as "the backbone of the medical system" given that they are the initial component of patient care. ${ }^{[1]}$ Therefore, it is crucial to ensure their well-being and work-life balance to maintain nursing quality and thus quality of healthcare facilities. Nursing is an undeniably stressful and demanding occupation with long and irregular hours, health and safety hazards, heavy workload, patient-related stressors, low wages, and sleep disruption. ${ }^{[2-5]}$ Occupational stress can be problematic when overstressed nurses are unable to provide quality care and may suffer from mental and physical health issues, engage in workplace disputes, have excessive absences, or resign from their jobs. ${ }^{[1]}$ It is essential that healthcare providers examine their organizational culture to ensure a supportive climate that will maximize the well-being and work-life balance of nurses. Improving the organizational culture will enable nurses to provide top quality medical care, be more productive, and enhance patient satisfaction.

\section{Organizational CUlture}

Organizational culture has a strong influence on work lifebalance ${ }^{[6]}$ and stress levels among employees. Anderson et al. ${ }^{[7]}$ stated that work-life conflict has been improved with flexible schedules and job autonomy or control, two factors related to organizational culture in hospitals. Flexible schedules and other policies viewed as family friendly have been associated with decreased absenteeism, increased job satisfaction, increased organizational commitment and enhanced productivity. ${ }^{[7,8]}$ Many aspects of nursing, such as variable workload, frequency of dealing with death, level of physician conflict, are more difficult to control, ${ }^{[9]}$ making those areas that do allow for greater control even more significant to create the perception of autonomy in the workplace. Autonomy has been cited as a major factor determining occupational stress levels in nurses. ${ }^{[10]}$ Autonomy has been frequently related to job satisfaction, ${ }^{[11]}$ higher productivity ${ }^{[8]}$ and performance, ${ }^{[12]}$ lower absenteeism, ${ }^{[13]}$ and better physical and mental health. ${ }^{[13,14]}$ Therefore, increased autonomy should

*Correspondence: Mrinal M. Varma, Assoc. Prof.; Email: mugdh@uhcl.edu; Address: University of Houston-Clear Lake, Houston, United States. 
translate into enhancing work-life balance.

Mrayyan $^{[15]}$ claimed that the level of nurse autonomy is related to leadership style, and a good leader can directly influence work-life quality as well as nurse satisfaction and retention. Nurses generally report having autonomy in patient care, but autonomy in unit functioning is established only with a participative leader and the organizational culture they create. These leaders tend to be "open-minded, and facilitate team communication, conflict handling, and shared decision-making" (p. 333). However, other aspects of hospital organizational culture, namely excessive workload and nurse-physician inequity have been found to undermine nurse autonomy.

Another impactful aspect of the work environment is organizational support. ${ }^{[6]}$ In a meta-analysis, Meyer, Stanley, Herscovitvh, and Topolnytsky ${ }^{[16]}$ found that the perception of organizational support increased employee commitment and suggested that fair treatment and strong leadership help establish a supportive culture. However, Behson ${ }^{[17]}$ found that informal work-life balance improvements are more functional than formal ones. Therefore it is crucial to both develop policies to address work-life conflict and ensure that supervisors support them. ${ }^{[18]}$ Without organizational cultural change, these policies only produce the perception of employee support while still making the same demands of employees which cause work-life conflict. ${ }^{[19]}$ Allen ${ }^{[18]}$ found that the degree to which the organization was perceived as supportive of family life mediated the relationships between family friendly policies, supervisor support, work-life conflict, organization commitment, and job satisfaction.

Coworker and supervisor support has also been found to influence work-life conflict, thus supervisors and employees should be trained to create a supportive work environment, including training in conflict resolution and providing social support. ${ }^{[20]}$ Zangaro and Soeken ${ }^{[11]}$ stated that a positive work environment has been found to enhance job satisfaction and lessen job stress. Coworker, supervisor, and physician interactions are important factors in creating a positive work environment. Nurses who report workplace social support and good communication are less likely to report an intention to leave the field ${ }^{[21]}$ and have also been found to be in better physical and mental health. ${ }^{[14]}$

Additionally, healthcare providers should offer training to instruct employees on how to actively cope. Some employees cope better with potential work stressors than others and are able to prevent work-life conflict. Many of these factors are individual differences, such as self-control, ${ }^{[22]}$ hardiness, and extraversion, ${ }^{[23]}$ which are difficult to develop if they are problematic. However, one crucial factor is active cop- ing, such as actively seeking social support, ${ }^{[9]}$ which has greater potential for enhancement through training. Another form of active coping is the use of problem-based coping to efficiently determine the best course of action for dealing with work and life stressors, but it appears to apply mainly to stressors viewed as under the control of the individual, which are more likely in the home. ${ }^{[20]}$ However, training in problem-based coping may prevent the perception of worklife conflict, which can be created if individuals attempt an avoidance strategy to stressors. Overall, training in active coping can enhance employee well-being and work-life balance.

\section{WORK-LIFE CONFLICT AMONG NURSES}

The plethora of stressors nurses face in their workplace can affect their physical health and well-being. Additionally, many nurses are also care givers at home. ${ }^{[3]}$ Both occupational and home stress can bleed into the other sphere, disrupting coping ability and work-life balance. ${ }^{[24]}$ Overall, hospital administration must address work-life balance and occupational stress for the welfare of both the individual nurse and the corporation.

The vast majority of nurses throughout the world are women. ${ }^{[25]}$ Gender is an influential factor in behavioral health, with women postulated to be exposed to more actual and perceived stressors. ${ }^{[26]}$ Burke and Greenglass ${ }^{[27]}$ stated that conflict is greater for women because they perform more of the family and home responsibilities than men, which can lead to lower psychological well-being. For nurses, this situation is even more complicated because they often have to provide care to family before and after work and professional care throughout their shift, thus being forced to balance two identities built on caring for others. ${ }^{[28]}$

Overall, the extensive caring in multiple realms and exposure to so many potential stressors combine to affect work-life integration. Schulter et al. ${ }^{[3]}$ found that "occupational stress is increasing in many industrialized countries, and can lead to nurse burnout, job dissatisfaction and increased nurse turnover" (p. 32). Simon et al. ${ }^{[24]}$ found that shift work and coerced overtime both increased work-life conflict which, in turn, was associated with potential turnover. This situation is not ideal for the individual nurse who suffers and leaves her job, but it also negatively impacts the healthcare provider, the nurses who remain, and patient care. The current nurse shortage has created a cycle in which increased workload and other factors, such as increased overtime, has led to decreased job satisfaction and increased work-life conflict, causing some nurses to resign. Nurse departures increase the workload for the remaining nurses, "a direct cause of stress and burnout and ultimately leads to low job satisfac- 
tion", which may cause more turnover(p. 606). ${ }^{[21]}$ Even if an individual is determined to stay, working as a nurse with extreme staff shortages increases workload which can reduce patient care quality, leading to more complaints and negative interactions as well as lower job satisfaction and increased exhaustion. Additionally, a portion of potential nurses may never enter the workforce because of the anticipated worklife conflict, thus exacerbating the nursing shortage. ${ }^{[26]}$ Additionally, Grzywacz et al. ${ }^{[29]}$ stated that work-life conflict has been associated with diverse negative outcomes; namely job dissatisfaction, psychological and physical health symptoms, burnout, medical errors, and lower quality care. All of these negative outcomes interact with the current worldwide nurse shortage ${ }^{[21]}$ and the high organizational costs of turnover, making policies that decrease work-life conflict essential for enhancing recruitment and retention of employees. ${ }^{[8]}$

\section{MODEL}

A model was developed to inform policy on work-life balance for nurses working for healthcare providers using the key stressors and stress attenuators suggested by the literature review (see Figure 1). The authors generated a list of stressors from the literature and categorized them into two potential occupational stressors. The first factor is Job Related Stressors, which refers to aspects of the healthcare facility such as safety and equipment, workload, patient interactions, job security, and employee value. Inadequate equipment and safety risks are stressors that can easily addressed. Other stressors may be more difficult to improve. With the nursing shortage in many countries ${ }^{[21]}$ and with many hospitals running at lower staff levels to save money, nurses may be faced with extremely high patient loads and the perception of job insecurity, which can contribute to stress and work-life imbalance. Stressful and emotional patient interactions, such as aggressive patients or patient loss, are a component of nursing, but they are likely to fluctuate by shift. Employee value is related to compensation and benefits, which may be difficult to change, but is also influenced by components of Organizational Culture, Support Systems, and Training.

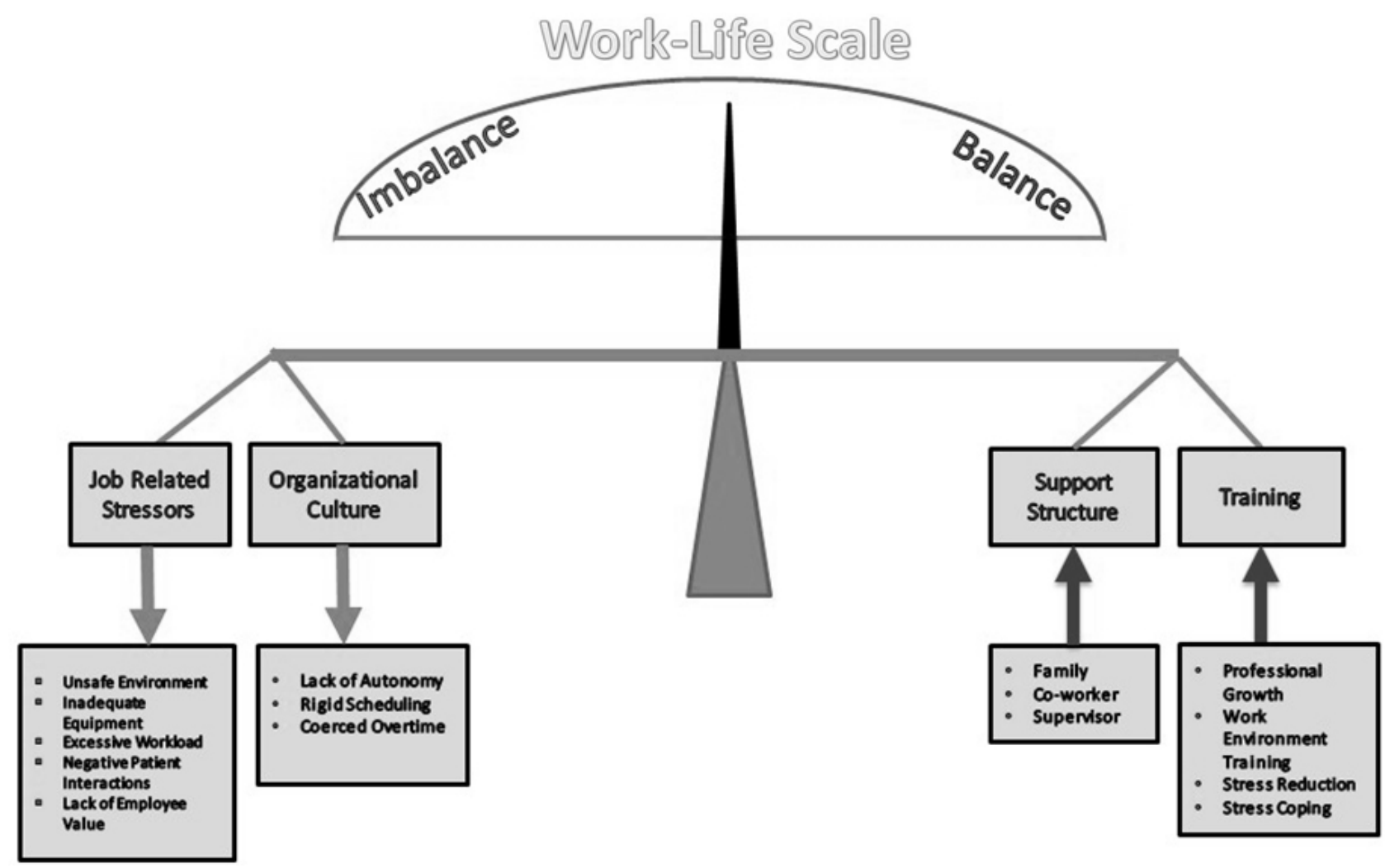

Figure 1. A model to address how four aspects of work and life interact to determine the level of work-life balance for nurses

The second factor is Organizational Culture, which refers to how much the health care organization is employee focused and family friendly, both in actuality and perception. For in- stance, Nejati et al. ${ }^{[30]}$ found that a well-designed break area, enhancing the work environment, and encouraging nurses to take restorative breaks led to higher ratings of nurse satisfac- 
tion and retention. A key factor to Organizational Culture is autonomy, which will also enhance perception of employee value. Policies encouraging nurse autonomy, such as allowing choice in scheduling and preventing coerced overtime, can help alleviate work-life imbalance.

The authors also generated a list of stress attenuators and categorized those into two factors. The first attenuator, Support Structure, refers to both the level of support from family and the workplace, from both co-workers and supervisors. Adequate support systems can buffer stress resulting from Job-Related or Organizational Culture factors. However, inadequate support will increase stress and work-life conflict.

The second attenuator is Training, which acts as a filter to determine if potential stressors become actual stressors. In addition to the job relevant skills, nurses need to be taught how to deal with other aspects of their career. Each healthcare organization should provide training on the safety and equipment relevant to their work environment. Additionally, training to deal with the emotional aspects of the job may improve nurse well-being and work-life balance. For instance, training nurses on yoga, mindfulness-based stress reduction, and psychosocial intervention programs have all been shown to reduce stress and burnout. ${ }^{[31,32]}$ Therefore, adding some sort of stress reduction training may be effective and improve the lives of nurses and the quality of care.

In many situations, these factors overlap. For example, many aspects of patient interactions cannot be altered, such as nurses having to occasionally deal with death of a patient or an aggressive patient, but autonomy and a structure of peer and supervisor support should aid in the ability of nurses to

\section{REFERENCES}

[1] Chen CK, Lin C, Wang SH, et al. A study of job stress, stress coping strategies, and job satisfaction for nurses working in middle-level hospital operating rooms. Journal of Nursing Research. 2009; 17(3): 199-211. PMid: 19738448. http://dx.doi.org/10.1097/JNR .0b013e3181b2557b

[2] Bogossian F, Winters-Chang P, Tuckett A. "The Pure Hard Slog That Nursing Is...": A Qualitative Analysis of Nursing Work. Journal of Nursing Scholarship. 2014; 46(5): 377-388. PMid: 25163354. http://dx.doi.org/10.1111/jnu. 12090

[3] Schluter P, Turner C, Huntington A, et al. Work/life balance and health: the Nurses and Midwives e-cohort study. International Nursing Review. 2011; 58(1): 28-36. PMid: 21281290. http: //dx.doi.org/10.1111/j.1466-7657.2010.00849.x

[4] Oomen H, Wright M, Maijala H. Stress-promoting and stressrelieving factors among nurses in rural India: a case study. Diversity in Health and Care. 2010; 7: 189-200. cope with these situations. Additionally, employee value, a component of Organizational Culture, could be fostered through a well-developed peer and supervisor Support Structure, not just in level of compensation or job security.

As all of these factors combine, they become occupational stress and can lead to work-life imbalance which creates an Attenuated Stress Level. Stress screening tools are able to identify the areas causing the most stress and work-life imbalance and can suggest stress reduction and stress coping interventions that would be beneficial. For instance, high stress levels may indicate the need for training on relaxation strategies, or feelings of low employee value could indicate the need to enhance perceived value through support or other changes to Organizational Culture to increase retention, crucial during the worldwide nursing shortage. Moreover, stress resulting from patient interactions, which are difficult to alter, may indicate the need for peer support groups that allow nurses to talk to others about the emotional side of their jobs to enable them to cope. Addition of the intervention that would address the major sources of stress and work-life conflicts should help enhance nurse satisfaction, retention, and well-being. Interventions should be combined with frequent screenings to identify any potential stressors before they become problematic. This combination should create a supportive work environment that maximizes nurse well-being and work-life balance to create a satisfied and productive work force. This situation would be beneficial for the employees and healthcare providers, making the investment in employee well-being immensely valuable.

\section{CONFlicts of INTEREST Disclosure}

The authors declare they have no conflicts of interest.
[5] Dollard MF, Dormann C, Boyd CM, et al. Unique aspects of stress in human service work. Australian Psychologist. 2003; 38(2): 84-91. http://dx.doi.org/10.1080/00050060310001707087

[6] Thompson CA, Prottas DJ. Relationships among organizational family support, job autonomy, perceived control, and employee well-being. Journal of occupational health psychology. 2006; 11(1): 100. PMid: 16551178 . http://dx.doi .org/10.1037/1076-899 8.10.4.100

[7] Anderson SE, Coffey BS, Byerly RT. Formal organizational initiatives and informal workplace practices: Links to work-family conflict and job-related outcomes. Journal of management. 2002; 28(6): 787810.

[8] Batt R, Valcour PM. Human resources practices as predictors of work-family outcomes and employee turnover. Industrial Relations: A Journal of Economy and Society. 2003; 42(2): 189-220. http: //dx.doi.org/10.1111/1468-232x.00287

[9] Huntington A, Bidewell J, Gilmour J, et al. The relationship be- 
tween workplace stress, coping strategies and health status in New Zealand nurses. Journal of Occupational Health and Safety. 2008; 24(2): 131-141.

[10] Mauno S, Kinnunen U, Ruokolainen M. Exploring work-and organization-based resources as moderators between work-family conflict, well-being, and job attitudes. Work \& Stress. 2006; 20(3): 210-233. http://dx.doi.org/10.1080/02678370600999969

[11] Zangaro GA, Soeken KL. A meta-analysis of studies of nurses' job satisfaction. Research in Nursing \& Health. 2007; 30(4): 445-458. PMid: 17654483. http://dx.doi.org/10.1002/nur. 20202

[12] Weston MJ. Strategies for enhancing autonomy and control over nursing practice. Online J Issues Nurs. 2010; 15(1).

[13] Enns V, Currie S, Wang J. Professional autonomy and work setting as contributing factors to depression and absenteeism in Canadian nurses. Nursing Outlook. 2015; 63(3): 269-277. PMid: 25982767. http://dx.doi.org/10.1016/j.outlook. 2014.12.014

[14] Killien MG. Nurses' health: work and family influences. Nursing Clinics of North America. 2004; 39(1): 19-35. PMid: 15062725. http://dx.doi.org/10.1016/j.cnur.2003.11.002

[15] Mrayyan MT. Nurses' autonomy: influence of nurse managers' actions. Journal of advanced nursing. 2004; 45(3): 326-336. PMid: 14720250. http://dx.doi.org/10.1046/j.1365-2648.2003 $.02893 . \mathrm{x}$

[16] Meyer JP, Stanley DJ, Herscovitch L, et al. Affective, continuance, and normative commitment to the organization: A meta-analysis of antecedents, correlates, and consequences. Journal of vocational behavior. 2002; 61(1): 20-52. http://dx.doi.org/10.1006/j vbe. 2001.1842

[17] Behson SJ. The relative contribution of formal and informal organizational work-family support. Journal of Vocational Behavior. 2005; 66(3): 487-500. http://dx.doi.org/10.1016/j.jvb.2 004.02 .004

[18] Allen TD. Family-supportive work environments: The role of organizational perceptions. Journal of vocational behavior. 2001; 58(3): 414-435. http://dx.doi.org/10.1006/jvbe. 2000.1774

[19] Harrington B, James JB. The standards of excellence in work-life integration: From changing policies to changing organizations. PittCatsouphes, M., Kossek, E. and Sweet, S. The Work and Family Handbook, Multi-disciplinary perspectives and approaches. Mahwah, NJ: Lawrence Erlbaum Associates; 2005. 665-83 p.

[20] Rotondo DM, Carlson DS, Kincaid JF. Coping with multiple dimensions of work-family conflict. Personnel Review. 2003; 32(3): 275-296. http://dx.doi.org/10.1108/00483480310467606

[21] Chan ZC, Tam WS, Lung MK, et al. A systematic literature review of nurse shortage and the intention to leave. Journal of Nurs- ing Management. 2013; 21(4): 605-613. PMid: 23406374. http: //dx.doi.org/10.1111/j.1365-2834.2012.01437.x

[22] Baltes BB, Heydens-Gahir HA. Reduction of work-family conflict through the use of selection, optimization, and compensation behaviors. Journal of Applied Psychology. 2003; 88(6): 1005. PMid: 14640812. http://dx.doi.org/10.1037/0021-9010.88.6.1 005

[23] Frone MR. Work-family balance. In: Quick JC, Tetrick LE, eds. Handbook of occupational health psychology. Washinton, D.C.: APA; 2003. 143-162 p. http://dx.doi.org/10.1037/10474-007

[24] Simon M, Kümmerling A, Hasselhorn HM. Work-home conflict in the European nursing profession. International journal of occupational and environmental health. 2013; 10(4): 384-91. PMid: 15702752. http://dx.doi.org/10.1179/oeh.2004.10 .4 .384

[25] World Health Organization. The World Health Report 2006 - Working Together For Health. 2006. Available from: http://www. who. int/whr/2006/en/

[26] World Health Organization. Mental Health: New Understanding, New Hope. World Health Organization. 2001. Available from: http: //www . who.int/whr/2001/en/whr01_en.pdf?ua=1

[27] Burke RJ, Greenglass ER. Work-family conflict, spouse support, and nursing staff well-being during organizational restructuring. Journal of occupational health psychology. 1999; 4(4): 327. http: //dx.doi.org/10.1037/1076-8998.4.4.327

[28] Ross M, Rideout E, Carson M. Nurses' work: balancing personal and professional caregiving careers. The Canadian journal of nursing research $=$ Revue canadienne de recherche en sciences infirmieres. 1993; 26(4): 43-59.

[29] Grzywacz JG, Frone MR, Brewer CS, et al. Quantifying work-family conflict among registered nurses. Research in nursing \& health. 2006; 29(5): 414-426. PMid: 16977647. http://dx.doi.org/10.1002 /nur. 20133

[30] Nejati A, Shepley M, Rodiek S. A Review of Design and Policy Interventions to Promote Nurses' Restorative Breaks in Health Care Workplaces. Workplace health \& safety. 2016; 64(2): 70-77. PMid: 26814229. http://dx.doi.org/10.1177/2165079915612097

[31] Alexander G, Rollins K, Wong L. Yoga for Self-Care and Burnout Prevention Among Nurses. Workplace health \& safety. 2015; 63(10): 462. PMid: 26419795. http://dx.doi.org/10.1177/2165079 915596102

[32] Nowrouzi B, Lightfoot N, Larivière M, et al. Occupational Stress Management and Burnout Interventions in Nursing and Their Implications for Health Work Environments A Literature Review. Workplace health \& safety. 2015; 63(7): 308-15. PMid: 26084675. http://dx.doi.org/10.1177/2165079915576931 